\title{
Filling in the Gaps: Lessons Learned From Preservice Teachers' Partnerships With First Nations Students
}

\author{
Lynne V. Wiltse
}

University of Alberta

\section{Author Note}

Lynne V. Wiltse, Elementary Education, University of Alberta.

I am grateful to Social Sciences and Humanities Research Council (SSHRC) for the financial support that made this study possible.

\begin{abstract}
In this paper, I report on a school-university collaborative research project that examined ways to merge the out-of-school literacy resources with school literacy practices for First Nations students in a small city in Western Canada. The project involved three interconnected groups of research participants: (a) a teacher researcher study group; (b) students from the participating teachers' classes; (c) preservice teachers who were partnered with the students in literacy partnerships. Grounded in a "funds of knowledge" perspective, and utilizing ethnographic research methods, this qualitative study explored how students' linguistic and cultural resources from home and community networks were utilized to reshape school literacy practices through their involvement in the Heritage Fair Program. This paper focuses on select lessons the preservice teachers learned through their partnerships with the First Nations students. Study findings suggest that the collaboration increased preservice teachers' understanding of how Aboriginal culture could contribute to more successful teaching practices.
\end{abstract}

Keywords: funds of knowledge; preservice teachers; literacy practices; racism

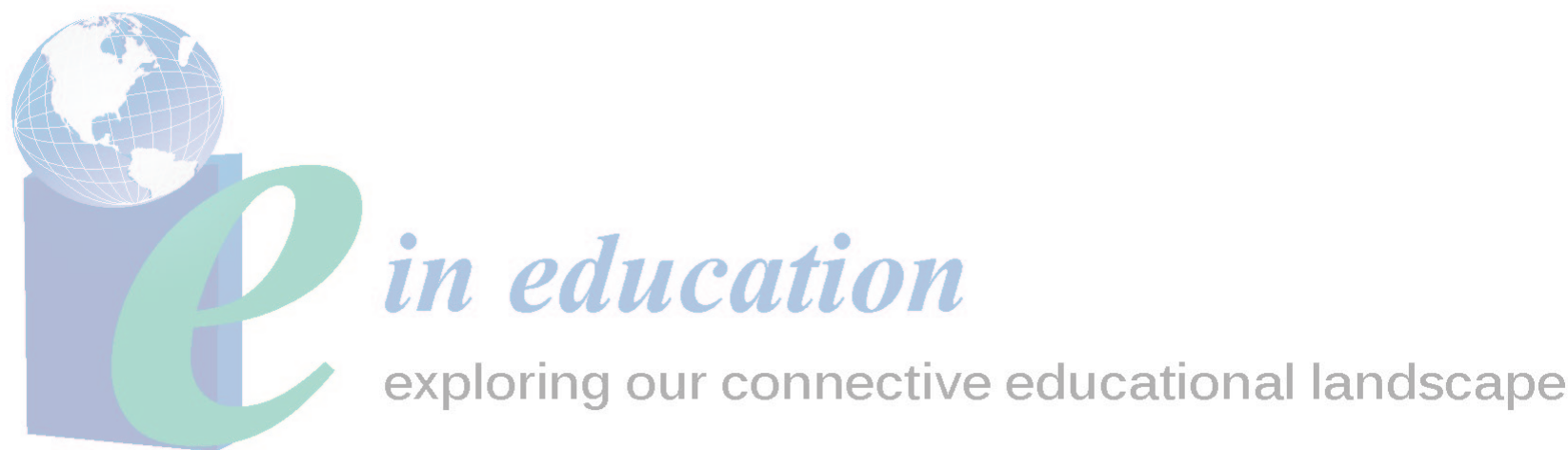




\section{Filling in the Gaps: Lessons Learned From Preservice Teachers' Partnerships With First Nations Students}

As I was scanning the titles in a recent issue of the Canadian Journal of Education, the title of an article, Are You Providing an Education That is Worth Caring About? Advice to Non-Native Teachers in Northern First Nations Communities (Oskineegish, 2015), caught my attention. Memories of my first teaching position in a northern First Nations community 35 years ago filled my mind; doubts that I had provided such an education to my first students rose to the surface. Drawing on research that has been conducted with non-Native teachers in remote First Nations and Inuit communities (for example, Agbo, 2007; Berger \& Epp, 2007; Harper, 2000), Oskineegish (2015) makes the point that "many of the difficulties that teachers experience stem from a lack of training and preparation in culturally appropriate practices, a disconnection from community and feelings of isolation” (p. 3). Although my first teaching experience was in British Columbia, I faced similar challenges. My teacher education program had taught me little about linguistic and cultural diversity in general, and next to nothing about Aboriginal students in particular. ${ }^{1}$ I learned by trial and error, and I still cringe when I recall some of the mistakes I made. My lack of preparation for teaching in such a context was not the only reason that my initial teaching position was so difficult. I taught predominantly First Nations students in a district school where connections with the community were close to non-existent; that the school district was 200 miles away on a mostly gravel road was part of the problem. The lack of connection between school and community in my first teaching position deeply concerned me. Over the next several years, I taught at two band-operated schools in First Nations communities, at the time housed in former residential schools (both were later replaced with new buildings). While the facilities were poor, connections to the community were strong, and in contrast to my first teaching experience, I could not help but notice the positive results for my students. In retrospect, I realize that this was because the expectations of and opportunities for culturally responsive teaching (Battiste, 2013; Chartrand, 2012; Kanu, 2011; Nardozi, Restoule, Broad, Steele \& James, 2014) were more readily available. These conflicting experiences shaped my career, first as a teacher in First Nations communities, and then as a teacher educator. Given that I was less than well prepared to begin teaching in a First Nations community, I have a vested interest in preparing preservice and in-service teachers for linguistically and culturally diverse classrooms.

Accordingly, this paper reports on a research project designed to examine which practices and knowledges of Canadian Aboriginal students not necessarily acknowledged in school may provide Aboriginal students with access to school literacy practices. The project was a schooluniversity collaboration, involving three interconnected groups of research participants: (a) a teacher researcher group; (b) Aboriginal students from the participating teachers' classes; (c) preservice teachers in my language and literacy curriculum classes who were partnered with students in the participating teachers' classes. Rather than the all-too-common remedial approach, this study took a different stance by stepping back from the notion that teaching and learning problems reside in the traits of students or their families to consider ways to merge the out-of-school resources of students with school literacies. This paper will focus on one aspect of the preservice teacher component of the study-the heritage fair partnerships. 


\section{Theoretical Framework}

The research was grounded in sociocultural theories of learning and teaching, which emphasize the inherently social and situated nature of learning, and view the activity of learners as positioned within the context of practice (Lave \& Wenger, 1991; Rogoff, 2003). Within a broad sociocultural framework, the study utilized third space theory, in conjunction with the concept of "funds of knowledge." Moje et al (2004) describe third spaces as hybrid spaces where the knowledges and discourses (Gee, 1996) from "the 'first space' of people's home, community and peer networks merge with the 'second space' of the Discourses they encounter in more formalized institutions such as work, school, or church” (p. 41). My research extended this view of third space in its consideration of how Aboriginal students' funds of knowledge (Moll, Amanti, Neff, \& Gonzales, 1992) from home and community networks can be utilized to reshape school literacy practices. Funds of knowledge are "the essential cultural practices and bodies of knowledge that households use to survive, to get ahead, or to thrive” (Moll \& Greenberg, 1990, p. 321). These perspectives complement work in the New Literacy Studies (Maybin, 2006; Street, 1999) and multiliteracies (Cope \& Kalantzis, 2000; Kress, 2000; New London Group, 1996). The New Literacy Studies build on the tradition of documenting literacy in local communities, giving prominence to out-of-school literacy practices, while multiliteracies advocate a multiplicity of channels for meaning-making, hybrid text forms, new social relations and the increasing prominence of linguistic and cultural diversity (Schultz \& Hull, 2002). Because these approaches view diversity as a resource rather than a deficit (Cummins, Chow, \& Schecter, 2006; Schecter \& Cummins, 2003), they open up literacy pedagogy to a wider range of learning and teaching. This is pertinent to my study as research suggests that many school literacy practices constrain access to school literacy practices, particularly for students from minority backgrounds (Gee, 2004; Pease-Alvarez \& Schecter, 2005; Toohey, 2000; Wiltse, 2006).

Parallel shifts have been occurring in the field of teacher education, with sociocultural perspectives on language and learning being integrated into preservice and inservice teacher education. The result is a more critical teacher education, which incorporates the view that teachers' responsibilities include challenging the marginalization of minority groups (CochranSmith; 2004; Hawkins, 2005; Willett \& Miller, 2004). As Canadian schools become increasingly linguistically and culturally diverse spaces (Ryan, Pollock \& Antonelli, 2009), this is important, given that practicing teachers in schools and candidates in teacher education programs remain predominantly White, monolingual, and middle class (Carson \& Johnston, 2000; Mujawamariya \& Mahrouse, 2004; Pirbhai-Illich, 2013).

\section{Research Methods and Context}

The research was a qualitative study, utilizing ethnographic research methods. I drew on the work of educational researchers who have used ethnographic studies to understand children's language and literacy practices, both in school (Maybin, 2006; Toohey, 2000; Wallace, 2005) and out-of-school (Long, Peck, \& Baskins, 2002; Schultz \& Hull, 2002). Within a broad ethnographic case study design, my research utilized students-as-researchers as a way to negotiate the politics of researching “other people's children” (Delpit, 1995). Data sources include field notes from classroom observations, heritage fair artifacts, preservice teachers’ case study assignments and transcripts from audiotaped teacher researcher meetings and semistructured interviews of select students and preservice teachers. Data for this paper are limited, 
for the most part, to the interviews and case study assignments of select preservice teachers. ${ }^{2}$

The study began with the teacher researcher group, which consisted of six teachers (three Aboriginal, three non-Aboriginal). We met on a monthly basis to explore pertinent sociocultural literature and to discuss related classroom practice. Three of the teachers taught at Wolfwood School, $^{3}$ the band-operated school on the nearby First Nations reserve, while the other three taught at inner city public schools with significant numbers of Aboriginal students. During the first term of the study, we made plans for the literacy partnerships between our respective students that would begin in the second term. It was an essential component of the study that whatever shape the literacy initiatives took would be decided with teacher input, and not be imposed by me. As I taught two classes of preservice teachers (30 students in each class), my intention was that the students of two of the teachers would be involved in the first year of the study. A Grade 5 teacher who taught for the local school district requested support for the science fair projects her students would be undertaking in the winter term. Another Grade 5 teacher, Gayle, who taught at Wolfwood School, wanted the mentorship to center on her students' heritage fair projects. The result was that one class of my preservice teachers collaborated with students for the science fair projects, while the other class worked with students on the heritage fair projects. This paper will focus only on the heritage fair collaboration, and on the preservice teachers' experiences. Because Gayle had fewer students in her class than I did, a small number of students from the Grade 4 and the Grade 6/7 classes participated so that each preservice teacher had a partner (the teachers of these students were also research participants, from the teacher researcher group). Data for this paper is from the first year of the study; however, due to its success during the first year, in the second year all three of the teachers at Wolfwood School involved their students in the heritage fair partnerships.

The preservice teacher participants were education students at a small primarily undergraduate university in the interior of British Columbia. For the research project, one of my classes was partnered with students in Grades 5 who attended Wolfwood School, operated by the local First Nations band. Just a few years old at the time of the study, the school followed the provincial Ministry of Education curriculum, in addition to offering programming in Aboriginal language, history, and culture. The school was situated next to the former residential school, which now houses band offices and a museum on the history of Indian Residential Schools (IRS); many of the students had relatives who had attended the residential school. From our classroom window at the university, we could see both buildings across the river that wound its way through the valley. The partnerships between the students and preservice teachers centered on the Heritage Fair Program (also known as Historica), a multi-media educational program developed to increase awareness and interest in Canadian history, unique community events and/or family culture. Students undertake research in developing their projects and present their completed displays at school, regional and/or provincial fairs. My preservice teachers were paired with the students as part of a case-study assignment "that places the teacher-education student in the role of researcher, investigating pedagogically relevant questions” (Sleeter, 2005, p. xii). Over the course of the project, four visits were made to the school during course time for partners to meet. Through the one-to-one mentorship, the students received support with research, data collection, writing, and visual representation, while the preservice teachers had the opportunity to learn about children's language and literacy practices in a situated approach, and to learn from the partnerships with students from a First Nations community. 
I received research ethics approval for the study from the Human Subjects Committee at the university in which I conducted the research. Approval was granted in two stages, first for the teacher participants in the teacher-researcher group, and later, for the students and preservice teachers when the partnerships were to begin.

\section{Study Findings}

While there were exceptions, study findings indicated that the preservice teachers, by and large, were not well-prepared for teaching Aboriginal students. Some had stereotypic notions of these students and their families, while others lacked an understanding of the historical and contemporary realities of Aboriginal communities. At the same time, the research suggested that an engagement with students from diverse backgrounds offers one possibility for preservice teachers to begin to understand how "learning to teach means coming to terms with particular orientations toward knowledge, power and identity” (Britzman, 2003, p. 33).

\section{Stereotypes, Misconceptions, and Gaps}

In February 2015, Maclean's magazine published a feature issue on Canada's problem with racism directed towards Aboriginal Canadians, and the claim that Winnipeg is the most racist city in Canada. In the article, Nancy Macdonald (2015) reports that "one in three Prairie residents believe that many racial stereotypes are accurate” (p. 19). This statistic is higher than reported elsewhere in Canada. Although the research for my project was conducted in British Columbia, not in one of the Prairie Provinces, study findings yielded no shortage of racial stereotypes in Canada's most western province. For example, while many of the preservice teachers had limited personal experience with Aboriginal people, they were familiar with the stereotypes. A case in point is Sandra. In the following interview excerpt, Sandra explains: "I've lived here pretty much my whole life and you definitely don't hear great things about Native people. Yeah, that they're lazy, that they're poor, that they behave poorly." Another illustration can be found with Carolyn: "Well, in the past, I have heard people talk about stereotypes, describing how some First Nations groups are uneducated and they can't articulate clearly." While these students make the point of describing what they have heard, not what they necessarily think, one of their classmates, Marilyn, explains how her personal biography left her with preconceived notions about Aboriginal people:

Being from Northern Saskatchewan, I grew up with that idea that they're poor, and they're less educated. My grandmother was a foster mom and she took in a lot of Aboriginal children and I had the idea they were abandoned, they were rejected, and that many of them had FAS (fetal alcohol syndrome). So, that was always my perspective because that's what I had been exposed to.

The preservice teachers’ comments call to mind Vetter, Haig-Brown and Blimkie’s (2014) research that describes a First Nations, Métis, and Inuit cross-curricular infusion in teacher education at York University's Faculty of Education, Barrie Site. This culturally responsive teaching came about from conversation with preservice teachers, the majority of whom were nonAboriginal. Vetter et al (2014) note that two major gaps existed in their understandings:

The first gap represented the issues that had been omitted from their prior education, such as the existence and intergenerational impact of residential schooling. The second gap encompassed what they thought they knew and how 
that knowing was often misconstrued by misconceptions and stereotypical beliefs.

(pp. 309 - 310)

In like vein, the remarks shared by my research participants demonstrate ways in which their knowing was affected by misconceptions and stereotypes.

The similarities between the two studies regarding gaps in understandings continued with omissions from the participants' previous education. A number of the preservice teachers in my project noted that they had learned very little about IRS) experiences in their own schooling. Susan, for example, describes the partnership at Wolfwood School as her "first experience with Aboriginal people. Growing up, I didn't have any friends or classmates who were Aboriginal.” In the following interview excerpt, Susan laments not having learned about Aboriginal people and issues earlier:

I had the very general stereotype of how Aboriginal people or First Nations chose not to be part of our community, and to live on reserve land, all of those claims that were more about how we came in and took over and tried to change them so much that we forgot to understand who they were and to try to work together instead. I found that I was glad to learn about that. But, I was shocked that I don't remember that being a part of my school curriculum. I wish that I'd known more because it would have made me more sensitive to seeing stories in the media or just hearing, "Oh that's another drunk so and so on the road.” I don't like that, but that's what's out there.

Astonishingly, for many of the research participants in my study, until their coursework in the education program, this type of racism was "what's out there." That they had got this far without having such stereotypical views and misconceptions disrupted speaks to the gaps in our education system regarding Aboriginal issues. Fortunately, there was more than one course in their program in which these preservice teachers learned about Aboriginal history and contemporary issues. Concurrent with the language and literacy course in which the research project was situated (the first year of a two-year program), they had a history of education course in which they learned about residential schooling; in the second year of the program, they would also take a course entitled, Teaching First Nations Children. ${ }^{4}$ Does the coursework make a difference? Susan's comment, a continuation of her previous remarks, suggests that that the answer may be a partial yes:

I'm disappointed that it wasn't part of my education, 'cause I feel like it could have been a little bit different, understanding where their families would be coming from in terms of residential schools. I can’t even imagine how that must have been. I don't know if I feel guilt per se, but I just feel so badly that I didn’t know about this before.

Whether coursework alone can result in substantive change is a pertinent query. In response to a racist comment posted on Facebook by a Winnipeg teacher, Brad Badiuk (reported in Maclean's), David Mandzuk, the Dean of Education at the University of Manitoba, acknowledged that, while education students have had to take at least two courses on Aboriginal education over the past five years, this might not be enough to result in substantive change in teachers' perspectives (Dhillon, 2014). I concur that coursework on its own will not suffice. For example, in their article, Examining Teachers' Beliefs About Teaching in Culturally Diverse Classrooms, Cabello and Burstein (1995) find that while education programs may attempt to alter the belief systems of preservice and in-service teachers, personal experience is more likely 
to effect change in their beliefs. It is also crucial to examine the affective domain of teaching and learning. Of significance here is Ottmann and Pritchard's (2010) literature review, Aboriginal Perspectives and the Social Studies Curriculum. The authors draw on numerous studies (for example, Clarke \& Drudy, 2006; Griffith \& Nguyen, 2006; Richards, Brown \& Forde, 2007; Yero, 2002) to demonstrate that, while knowledge and skill development is important for quality teaching and student learning, "teacher attitudes and perspectives influence learning and the teaching of Aboriginal perspectives” (p. 21). In brief, this research relates to my study in terms of emphasizing the need for teachers to be reflective and to explore their own backgrounds and feelings towards cultural difference. ${ }^{5}$ Research shows that this is more likely to happen if preservice teachers have opportunities for involvement with Aboriginal students as part of, or in addition to, their coursework. For example, Hare's (2015) study of instructors who were teaching a new required course on Indigenous education in a teacher education program at a university in Western Canada reveals that "effective teaching strategies with preservice teachers...include connecting with the Aboriginal community and learning from place” (p. 101). This is a key reason why I wanted my preservice teachers to be partnered with Aboriginal students in projects that included community involvement.

Susan's mention of White guilt, earlier, points to another possible issue related to coursework of this nature. Nancy, one of her classmates, expressed similar sentiments:

I have only recently begun to understand the horrors that White society inflicted on Aboriginal peoples. I feel very sorry, and although I personally was not responsible, I carry some of the guilt of the White people.

Studying difficult histories can indeed be challenging-how could it be otherwise? Learning about residential schooling and its aftermath can be considered "difficult knowledge," which Pitt and Britzman (2006) argue may include "narratives of historical traumas such as genocide, slavery, and forms of social hatred and questions of equity, democracy and human rights” (p. 379). But, this learning is crucial, if, as Susan suggests, the stereotypes and misconceptions that abound are to be disrupted. The preservice teachers were experiencing a measure of what Boler and Zembylas (2003) refer to as a "pedagogy of discomfort," one that recognizes and problematizes the daily habits and routines that are largely shaped by dominant values and assumptions and highlights gaps and absences in current curricular practices. It stands to reason that an introduction to difficult histories may cause discomfort. Nancy describes the impact of learning about the horrific legacy of residential schooling: "Due to my lack of experience with Aboriginal children and culture, I did not feel qualified to adequately meet the needs of the children at Wolfwood School.” Accordingly, Nancy hoped to be placed at the other school for the science fair project partnerships. Nancy's uneasiness is not unusual. An example can be found in Deer's (2013) study, an examination of the perceptions and attitudes of preservice teachers towards the integration of Aboriginal perspectives in education. Deer found that many of his research participants, most of whom were non-Aboriginal, experienced apprehension regarding the prospect of integrating Aboriginal perspective into the curriculum. Deer (2013) reported a number of reasons for the apprehension, including "fear of failure, discomfort with the subject matter, guilt, and not being Indigenous” (p. 204). My concern is whether or not such newfound knowledge will mobilize or immobilize future teachers. As Boler and Zembylas (2003) make clear, moving into a pedagogy of discomfort "can be very discomforting and demands substantial negative emotional labor such as vulnerability, anger, and suffering...However, emotional labor...can produce favorable results, including self-discovery, 
hope, passion and a sense of community” (p. 129). ${ }^{6}$ Had Nancy been given a choice, she would have avoided contact with Aboriginal students; clearly, this would have been a missed learning opportunity. Nancy goes on to explain: "I soon learned that my apprehension was unfounded because I had a fabulous learning experience. I enjoyed getting to know a great kid. I also observed a teacher who was an amazing role model for the kids and for myself.”

While Nancy was anxious about the partnerships at Wolfwood School, Marilyn, the participant from Northern Saskatchewan, approached the project influenced by preconceived ideas she brought with her to the program:

I thought that going to Wolfwood School would bring me face-to-face with students who were sheltered and disadvantaged. Unfortunately, that inhibited my idea of who Aboriginal children were.

Indeed, Marilyn's background experiences had drastically limited her perspective and understanding of Aboriginal students. Regrettably, her comments echo literature in the field. For example, in their study of preservice teachers' discriminatory judgments, Riley and Ungerleider's (2008) make the claim that "ascribed characteristics of race, ethnicity, sex, or even physical appearance...may influence a teacher's expectations even before the student has had an opportunity to perform” (p. 380). Given the lack of Canadian empirical studies to support claims of discrimination against Aboriginal students, Riley and Ungerleider (2008) designed a study to determine whether preservice teachers' judgments about the performance of Aboriginal students were discriminatory. Fifty preservice teachers were asked to assess the records of 24 students and to make placement decisions accordingly. Based on their assessments, students would be placed in remedial, conventional, or advanced programs. This study's findings showed that "preservice teachers systematically devalued the performance of students whom they were led to believe were of Aboriginal ancestry in comparison with their non-Aboriginal counterparts with identical student records” (Riley \& Ungerleider, 2008, p. 378). Had Marilyn begun teaching without having these impressions disrupted, the results would likely have been detrimental to any Aboriginal students she may have in future classrooms. The ways in which involvement in the project made a difference for Marilyn and her classmates will be explored in the following section.

\section{Filling in the Gaps and Disrupting Stereotypes}

My preservice teachers learned much from their partnerships with the students. The gaps in their understandings continued to narrow; at the same time, they also learned something about “cultivating student success for First Nations students” (Oskineegish, 2015, p. 1).

Marilyn's student partner, Pippa, played a significant role in shifting the negative preconceptions with which she began the project:

Pippa literally showed this to be quite false when she opened her scrapbook and showed me all the marvelous places she has been to. She was well versed, she didn't have a language barrier, and here we were talking about London and Scotland and it was so exciting. It changed who I was.

Pippa defied the stereotypes Marilyn held-Pippa was neither sheltered nor disadvantaged; rather, she was an excellent student, spoke fluent English, and had strong computer skills, as evidenced in the following comment: 
Pippa is fluent on the computer and was able to bypass the safety net the school set up for students when she wanted to show me something on YouTube. I was amazed at her Internet savvy; I could learn so much from her! Pippa's knowledge of the Internet gave her greater access to her heritage fair project topic-paranormal activity within Canada.

And, learn Marilyn did! In an interview, Pippa explained:

My dad's kind of like a computer geek so he shows me everything....and then I turn out to be a computer kid, too! Probably the hardest thing for my partner is that she never got how I did the pictures like that. It seems like I was teaching her. For example, I taught her a bit of how to add a picture.

During the course of the project, Pippa's father visited the class to give a lesson on how to add images downloaded from the Internet. As well, Pippa's father accompanied her in the field as she conducted research for her project (for example, they visited a former tuberculosis sanatorium which had the reputations of being haunted). Being witness to this type of family involvement in the students' heritage fair projects defied many of the preservice teachers' prior expectations. For instance, working with her partner, Alison, did not confirm the stereotypes that Sandra had grown up hearing about Aboriginal people. Alison completed her heritage fair project on Kenny McLean, an all-around "Indian cowboy." Sandra, who had "heard other people say things like...their parents don't want them” found that

Alison was just like a breath of fresh air, honestly. She was open. It was good for me to see because, even though her parents weren't together anymore, she had a strong family life, I could tell she was supported at home, while I expect there's some kids that go to that school that don't have that. With Alison, it was nice to see a happy well-balanced kid who liked school and liked talking about her family.

In an interview, Alison, who loved rodeo barrel racing, told me how she came to decide on her topic:

First I asked my stepdad, "What project should I do that's something Canadian, and something like rodeoing?” And he’s like, “How about Kenny McLean?” I said, “Sure, what does he do?” I found out he's an all-around world champion-he’s a bronc rider and he's a calf roper, team roper. That's how I decided to do Kenny McLean.

When it came to having stereotypes about parental involvement of Aboriginal students shattered, Carolyn's experience was similar. For her heritage fair project, aptly entitled Locked up Indians, her partner, Philippa, had interviewed her paternal and maternal grandmothers about their experiences in two different residential schools. Carolyn explained:

The past stereotypes that I've heard, Philippa was not a part of them at all. Her parents are very, very involved in her education and she said they were always asking about homework. She was proud that her dad was one of these managers in the natural resources, so they were always asking about things like what are you doing, what are you reading about, and it made a difference...Also, compared to myself, Philippa’s larger family group was involved, both grandmas and her aunt, in addition to her parents. 
Of course, parental/family involvement in a child's education makes a difference. As a teacher working with First Nations students, the most significant difference I noted when I moved from teaching at a district school to teaching at band-operated schools was the way that parents/family members played a more active role in their children's education. There were a number of interconnected reasons for this (for example, congruence in curriculum between community and school; culturally responsive teaching; fewer negative associations to their own school experiences). The literature on Aboriginal parents' involvement in their children's education emphasizes how crucial it is that teachers not make assumptions in this regard (see Aquash, 2013; Bell, 2013; Martin, 2015; Matthew, 2005; Murphy \& Pushor, 2004).

Not all the lessons learned were about disconfirming stereotypes or preconceived notions-for some of the preservice teachers, the lessons were about disrupting what they took for granted as non-Aboriginals, in particular as students of White privilege (Burleigh \& Burm, 2013; Gillborn, 2006). Over time, Nancy came to the realization that she was viewing her partner through a middle-class lens. Nancy was paired with Cheryl, whose heritage fair project was on the Echo Mask that had been in her grandfather's family before being confiscated during a potlatch in 1921 and exhibited at the Canadian Museum of Civilization. ${ }^{7}$ As part of the project, students were expected to conduct an interview; Nancy explained that Cheryl "wanted to interview her grandfather but did not know how since he lived several hours away." She continues:

At this point, I was still seeing this student through my White, middle-class lens, and I wondered why she couldn't just call her grandfather on the phone. Fortunately, before I asked a tactless question and revealed my ignorance, my partner told me that she couldn't phone her grandfather because buying a calling card would be expensive. Instead, I helped her write a letter to her grandfather. When she was done, she informed me that she did not know where she could get an envelope or a stamp. In my middle class world, long distance phone calls, envelopes, and stamps are part of everyday life.

In her book, Reading Classes: On Culture and Classism in America, Jensen (2012) examines the ways in which middle-class teachers and administrators often misunderstood, ignored, or disrespected working-class children. While the context of Aboriginal students in Canada is markedly different from that of Jensen's (2012) study, the similarity to my research is in the ways in which students are often misunderstood, ignored, or disrespected. Not all students attending Wolfwood School had family circumstances comparable to Pippa or Philippa. The legacy of residential schooling affected families in various ways; a number of the students lived in poverty; some came from homes where family members struggled with alcohol or substance abuse. This, too, was an important gap to address. One of my goals for the project was for my students to realize that not all Aboriginal people are the same; while this should be obvious; it is still an alltoo-common misunderstanding. Broad assumptions of any type regarding Aboriginal students (or of any group) are problematic. Rather than viewing children living in poverty or those from nonmainstream backgrounds from a deficit perspective (Comber, 2014; Dudley-Marling \& Lucas, 2009; Dyson, 2015; Sharma \& Portelli, 2014), educators need to consider how to lessen the "discontinuities that many children experience between their lives in- and out-of-school" (Comber, 2013, p. 361). Regardless of differences in family background, all the student participants brought funds of knowledge to school that could be utilized in their learning. 
As the heritage fair projects required the student participants to examine and document linguistic and cultural practices in their local communities (Egan-Robertson \& Bloome, 1998), they emphasized connections between home and community networks. I have written about the students' heritage fair projects as funds of knowledge elsewhere (Wiltse, 2014, 2015); for the preservice teachers, however, this was vital knowledge if they were to learn to teach from diversity as a resource perspective and to be positioned to create third spaces of improved literacy learning. Given space constraints, I will focus on one particularly pertinent example (in addition to the examples mentioned in brief in this paper). Darius, a 10-year-old boy who had recently moved from a small and isolated Aboriginal community in the northern corner of the province, was in his first year at Wolfwood School. Darius completed his project on hunting in Fort Wilson, a topic not only of personal interest, but also of family and community tradition (for example, he is the third generation of hunters, his uncle and grandfather taught him how to hunt, his grandmother makes jackets with the hides). According to his teacher, with the exception of his heritage fair project, Darius was rarely engaged in school literacies during the first year at his new school. His university partner, Kandy, who grew up in the lower mainland of B.C. describes her own schooling "as pretty much a bunch of White kids that lived all in the same area. 'Cause there was not really any variation of ethnicity that I was aware of, so I never even really thought about it.” The project at Wolfwood School was provoking her to think:

My partner actually got to explore this aspect of his life in school so he was pretty excited about doing his heritage fair project on hunting. Darius told me that he doesn't really like writing or reading, so it was good that he could see that there are ways for him to write and read and enjoy it. He really learned a lot about writing by going through that process. This made me realize that I will need to find a way for kids to be able to learn their own way, whether it's about hunting or going fishing with dad, while still learning the same skills.

Kandy's comment suggests that she has begun to understand that funds of knowledge represent a "positive (and we argue, realistic) view of households as containing ample cultural and cognitive resources with great, potential utility for classroom instruction” (Moll et al., 1992, p. 134). The import of this cannot be overemphasized, as exemplified in the following:

Darius definitely said that he usually doesn't like writing very much in school but that he was excited about this project because he could find out about hunting and he got to call and talk to his uncle for the interview. So, it does help that he actually got to explore this aspect of his life in school.

That Darius was able to explore hunting, something he loved from his out-of-school life, made a dramatic difference to the way in which he invested himself in the research and writing required for his project. As Amanti (2005) explains, incorporating funds of knowledge is not about "replicating what students have learned at home, but about using students' knowledge and prior experiences as a scaffold for new learning” (p. 135).

\section{Going Forward}

In her article, Disrupting Molded Images, Dion (2007) examines the relationship between teachers and Indigenous subject material. Her view is that while teachers are being encouraged to include Aboriginal content across the curriculum, most "teachers, like the majority of Canadians, know little about Aboriginal people, history, and culture” (Dion, 2007, p. 330); rather their 
understanding is informed by dominant discourses (Schick \& St. Denis, 2005). Similarly, Scully (2015) makes the point that while "Indigenous education in teacher education must prioritize addressing the learning needs of Indigenous students, it must also serve to shift the gravely lacking common knowledge of most Canadians regarding Indigenous peoples in Canada” (p. 81). The project that my preservice teachers were involved in played a part, albeit small, in disrupting dominant discourses. Susan describes how this experience, in conjunction with what she had learned in coursework, had increased her awareness of "issues that had been omitted from their prior education”:

So I think, it's brought all of that together for me. I don't really know how I'm going to go forward with it, but at least it's there. I'm a lot more conscious of what I say and how I say it and how I'm viewing certain situations. And hopefully, if I come across negative comments by family members or other people, I'll have more of the strength and information behind me to make an argument that I can back up.

As Aboriginal journalist Wab Kinew contends, "Reconciliation with Native People is still the most pressing social justice issue Canada faces” (White, 2013). The comments made by Susan and some of her classmates leave no doubt. Since the completion of the research project reported on in this paper, the Truth and Reconciliation Commission of Canada on residential schooling has taken place in Canada, resulting in 94 Calls to Action. No longer should any Canadian student be able to say that he or she did not learn about residential schooling and its legacy in school. ${ }^{8}$

In terms of the second gap, how what students thought they knew was "misconstrued by misconceptions and stereotypical beliefs” (Vetter, Haig-Brown \& Blimkie, 2014, pp. 309 - 310), I return to Marilyn, who had misperceptions and low expectations of Aboriginal students. Marilyn reported a change triggered by her partnership with Pippa:

It will change my perspective and my teaching as well because I will not come into the classroom with such a low expectation or a low understanding of Aboriginal students. I will actually say, where have you been and what have you done, rather than have the preconceived idea that just because a child is Aboriginal doesn't mean that they are not well traveled or well spoken or do not have the experiences that an average Caucasian child has.

Given the research on teachers' expectations of Aboriginal and other minority students, this is promising. In considering the implications of Marilyn's comments, I revisit Riley and Ungerleider's (2008) study. These authors draw on research that concluded that "the selffulfilling prophecy effects that occur in one year may, on average, lead to small differences between targets of high and low expectations that endure for a very long period" (Smith, Jussim \& Eccles, 1999, p. 563) to emphasize their argument as to how preservice teachers' discriminatory judgments can drastically affect the academic achievement and opportunities of Aboriginal students. In closing, I return to Carolyn, who began the project having heard many negative stereotypes about Aboriginal people. When I asked Carolyn what she had learned from her partnership with Philippa that would impact her as a future teacher, her response was, "Well, that you can’t judge a book by its cover; you definitely can't. If you label, you get what you expect." This is a cliché, perhaps, but significant learning nonetheless. Had I had a comparable experience in my teacher education program, I may have done better justice to providing the 
Aboriginal students from my first teaching position an education that was worth caring about. For practicing teachers who are working in First Nations communities, Oskineegish (2015) recommends self-reflection, communication and community engagement, and having the right kind of attitude. This excellent advice I learned over the course of my teaching career, unfortunately a little too late for my first students. 


\section{References}

Agbo, S. (2007). Addressing school-community in a cross-cultural context: A collaborative action to bridge the gap between First Nations and the school. Journal of Research in Rural Education, 22(8), 1 - 14.

Amanti, C. (2005). Beyond a beads and feathers approach. In N. Gonzáles, L. Moll, \& C. Amanti (Eds.), Funds of knowledge: Theorizing practices in households, communities and classrooms (pp. 131 - 141). London, UK: Lawrence Erlbaum Associates.

Aquash, M. (2013). First Nations control of education: One community's experience. Canadian Journal of Native Education, 36(1), 59 - 76.

Battiste, M. (2013). Decolonizing education: Nourishing the learning spirit. Saskatoon, SK: Purich.

Bell, N. (2013). Just do it: Anishinaabe culture-based education. Canadian Journal of Native Education, 36(1), 36 - 58.

Berger, P., \& Epp, J. (2007). “There’s no book and there’s no guide”: The expressed needs of Qallunaat educators in Nunavut. Brock Education, 16(2), 44 - 56.

Boler, M., \& Zembylas, M. (2003). Discomforting truths: The emotional terrain of understanding difference. In P. P. Trifonas (Ed.), Pedagogies of difference: Rethinking education for social change (pp.110 - 136). New York, NY: RoutledgeFalmer.

Britzman, D. (2003). Practice makes practice: A critical study of learning to teach. Albany, NY: State University of New York Press.

Burleigh, D., \& Burm, S. (2013). Unpacking our White privilege: Reflecting on our teaching practice. in education, 19(2), 107 - 119.

Cabello, B., \& Burstein, N. (1995). Examining teachers' beliefs about teaching in culturally diverse classrooms. Journal of Teacher Education, 46(4), 285 - 294.

Carson, T., \& Johnston, I. (2000). The difficulty with difference in teacher education: Toward a pedagogy of compassion. The Alberta Journal of Educational Research, 46(1), 75 - 83.

Chartrand, R. (2012). Anishinaabe pedagogy. Canadian Journal of Native Education, 35(1), 144 $-221$.

Cochran-Smith, M. (2004). Walking the road: Race, diversity, and social justice in teacher education. New York, NY: Teachers' College Press.

Comber, B. (2013) Schools as meeting places: Critical and inclusive literacies in changing local environments. Language Arts, 90(5), 361-371.

Comber, B. (2014). Getting out of deficit: Pedagogies of reconnection. Teaching Education, 15(3), 293 - 310.

Cope, B., \& Kalantzis, M. (2000). (Eds.). Multiliteracies: Literacy learning and the design of social futures. New York, NY: Routledge. 
Clarke, M., \& Drudy, S. (2006). Teacher for diversity, social justice, and global awareness. European Journal of Education, 29(3), 371 - 386.

Cummins, J., Chow, P., \& Schecter, S. (2006). Community as curriculum. Language Arts, 83(4), $297-307$.

Deer, F. (2013). Integrating Aboriginal perspectives in education: Perceptions of pre-service teachers. Canadian Journal of Education, 36(2), 175 - 211.

Delpit, L. (1995). Other people's children: Cultural conflict in the classroom. New York, NY: The New Press.

Dhillon, K. (2014, December 2). Brad Badiuk's 'racist' Facebook posts need action by Winnipeg school board: Trustee. Retrieved from http://www.cbc.ca/news/canada/manitoba/bradbadiuk-s-racist-facebook-posts-need-action-by-winnipeg-school-board-trustee-1.2870734

Dion, S. (2007). Disrupting molded images: Identities, responsibilities and relationships-teachers and indigenous subject material. Teaching Education, 18(4), 329 - 342.

Dudley-Marling, C., \& Lucas, K. (2009). Pathologizing the language and culture of poor children. Language Arts, 86(5), 362 - 370.

Dyson, A. H. (2015). The search for inclusion: Deficit discourse and the erasure of childhoods. Language Arts, 92(3), 199 - 206.

Egan-Robertson, A., \& Bloome, D. (Eds.). (1998). Students as researchers of culture and language in their own communities. Cresskill, NJ. Hampton Press.

Gee, J. P. (1996). Social linguistics and literacies: Ideologies in discourses. New York, NY: Falmer Press.

Gee, J. P. (2004). Situated language and learning: A critique of traditional schooling. New York, NY: Routledge.

Gillborn, D. (2006). Rethinking White supremacy: Who counts in 'Whiteworld'. Ethnicities, 6(3), 318 - 340.

Griffith, K. G., \& Nguyen, A. D. (2006). Are educators prepared to affect the affective domain? National Forum of Teacher Education Journal, 16(3E), 1 - 4.

Hare, J. (2015). “All of our responsibility”: Instructor experiences in the teaching of required Indigenous education coursework. Canadian Journal of Native Education, 38(1), 101 120.

Harper, H. (2000). “There is no way to prepare for this”: Teaching in First Nations schools in Northern Ontario-issues and concerns. Canadian Journal of Native Education, 24(2), 144 157.

Hawkins, M. (2005). Becoming a student: Identity work and academic literacies in early schooling. TESOL Quarterly, 39(1), 59 - 82.

Jensen, B. (2012). Reading classes: On culture and classism in America. London, UK: IRL Press. 
Kanu, Y. (2011). Integrating Aboriginal perspectives into the school curriculum. Toronto, ON: University of Toronto Press.

Kerr, J., \& Parent, P. (2015). Being taught by Raven: A story of knowledges in teacher education, Canadian Journal of Native Education, 38(1), 62 - 79.

Kress, G. (2000). Multimodality. In B. Cope \& M. Kalantzis (Eds.), Multiliteracies: Literacy learning and the design of social futures (pp. 182 - 202). New York, NY: Routledge.

Lave, J., \& Wenger, E. (1991). Situated learning: Legitimate peripheral participation. Cambridge, UK: Cambridge University Press.

Long, E., Peck, W., \& Baskins, J. (2002). STRUGGLE: A literate practice supporting life-project planning. In G. Hull \& K. Schultz (Eds.), School's out! Bridging out-of-school literacies with classroom practice (pp.131 - 161). New York, NY: Teachers College Press.

Macdonald, N. (2015, February 2). Welcome to Winnipeg: Where Canada's racism problem is at its worst. Maclean's, 128(4), 16 - 24.

Martin, G. (2015). Re-imagining Indigenous parent involvement in teacher education: One parent's experience in the public school system. Canadian Journal of Native Education, 38(1), 5 - 20.

Matthew, J. (2005). Parents of First Nations students: Perspectives of their roles as literacy supporters. (Unpublished master's thesis ).University of Victoria.

Maybin, J. (2006). Children's voices: Talk, knowledge and identity. New York, NY: Palgrave/Macmillan.

Moje, E., Ciechanowski, K., Kramer, K., Ellis, L., Carrillo, R., \& Collazo, T. (2004). Working toward third space in content area literacy: An examination of everyday funds of knowledge and discourse. Reading Research Quarterly, 39(1), 38 - 70.

Moll, L., Amanti, C., Neff, D., \& Gonzales, N. (1992). Funds of knowledge for teaching: Using a qualitative approach to connect homes and classrooms. Theory Into Practice, 31(2), 132 141.

Moll, L. \& Greenberg, J. (1990). Creating zones of possibilities: Combining social contexts. In L. C. Moll (Ed.), Vygostksy and education: Instructional implications and applications of sociohistorical psychology (pp. 319 - 348). New York, NY: Cambridge University Press.

Mujawamariya, D., \& Mahrouse, G. (2004). Multicultural education in Canadian preservice programs: Teacher candidates’ perspectives. Alberta Journal of Educational Research, 50(4), 336 - 353.

Murphy, B., \& Pushor, D. (2004). Parent marginalization, marginalized parents: Creating a place for parents on the school landscape. Alberta Journal of Educational Research, 50(3), 221 235.

Nardozi, A., Restoule, J.P., Broad, K., Steele, N., \& James, U. (2014). Deepening knowledge to inspire action: Including Aboriginal perspectives in teaching practice. in education, 19(3), $108-122$. 
New London Group. (1996). A pedagogy of multiliteracies: Designing social futures. Harvard Educational Review, 66(1), 60 - 90.

Oskineegish, M. (2015). Are you providing an education that is worth caring about? Advice to non-Native teachers in northern First Nations communities. Canadian Journal of Education, 38(3), 1 - 25.

Ottmann, J. with Pritchard, L. (2010). Aboriginal perspectives and the social studies curriculum. First Nations Perspectives 3(1), 21 - 46.

Pease-Alvarez, L., \& Schecter, S. (Eds.). (2005). Teaching and community: Contributions of situated and participatory approaches to educational innovation. Mahwah, NJ: Lawrence Erlbaum Associates.

Pirbhai-Illich, F. (2013). Crossing borders: At the nexus of critical service learning, literacy, and social justice. Waikato Journal of Education, 18(2), 79 - 96.

Richards, H. V., Brown, A. F., \& Forde, T. B. (2007). Addressing diversity in schools: Culturally responsive pedagogy. Teaching Exceptional Children, 39(3), 64 - 68.

Riley, T., \& Ungerleider, C. (2008). Pre-service teachers' discriminatory judgments. The Alberta Journal of Educational Research, 54(4), 378 - 387.

Rogoff, B. (2003). The cultural nature of human development. Oxford, UK: Oxford University Press.

Ryan, J., Pollock, K., \& Antonelli, F. (2009). Teacher diversity in Canada: Leaky pipelines, bottlenecks, and glass ceilings. Canadian Journal of Education, 32(3), 591 - 617.

Schecter, S., \& J. Cummins, J. (2003). Multilingual education in practice: Using diversity as a resource. Portsmouth, $\mathrm{NH}$ : Heinemann.

Schick, C., \& St. Denis, V. (2005). Troubling national discourses in anti-racist curricular planning. Canadian Journal of Education, 28(3), 295 - 317.

Schultz, K., \& Hull, G. (Eds.) (2002). School's out! Bridging out-of-school literacies with classroom practice. New York, NY: Teachers College Press.

Scully, A. (2015). Unsettling place-based education: Whiteness and land in Indigenous education in Canadian teacher education, Canadian Journal of Native Education, 38(1), 80 - 100.

Sharma, M., \& Portelli, J. (2014). Uprooting and settling in: The invisible strength of deficit thinking. Learning Landscapes, 8(1), 251 - 267.

Sleeter, C. (2005). Foreword. In L. Pease-Alvarez \& S. Schecter (Eds.), Teaching and community: Contributions of situated and participatory approaches to educational innovation (pp. xi-xii). Mahwah, NJ: Lawrence Erlbaum.

Smith, A., Jussim, L., \& Eccles, J. (1999). Do self-fulfilling prophecies accumulate, dissipate, or remain stable over time? Journal of Personality and Social Psychology, 77, 548 - 565.

Street, B. (1999). New literacies in theory and practice: What are the implications for language in education? Linguistics and Education, 19(1), 1 - 24. 
Taylor, E.W., \& Cranton, P. (2012). The handbook of transformative learning: Theory, research, and practice. San Francisco, CA: Jossey-Bass.

Toohey, K. (2000). Learning English at school: Identity, social relations and classroom practice. Toronto, ON: Multilingual Matters .

Wallace, C. (2005). Conversations around the literacy hour in a Multilingual London primary school. Language and Education, 19(4), 146 - 161.

White, D. (Producer). (2013, December 23). Canada Reads-The Orenda [Radio broadcast]. In Airplay. Whitehorse, YK: CBC.

Willett, J., \& Miller. S. (2004). Transforming the discourse of teaching and learning: Rippling waters and shifting sands. In M. Hawkins (Ed.), Language learning and teacher education: A sociocultural approach (pp. 52 - 88). Clevedon, UK: Multilingual Matters Press.

Wiltse, L. (2006). "Like pulling teeth”: Oral discourse practices in a culturally and linguistically diverse language arts classroom.” Canadian Modern Language Review, 63(2), 199 - 223.

Wiltse, L. (2014). Leaning over the fence: Heritage fair projects as 'funds of knowledge.' Alberta Journal of Educational Research, 60(2), 361 - 376.

Wiltse, L. (2015). "Not just “sunny days:” Aboriginal students connect out-of-school literacy resources with school literacy practices. Literacy, 49(2), 60 - 68.

Wiltse, L., Johnston, I., \& Yang, K. (2014). Pushing comfort zones: Promoting social justice through the teaching of Aboriginal Canadian literature. Changing English, 21(3), 263 276.

Vetter, D., Haig-Brown, C., \& Blimkie, M. (2014). Culturally responsive teaching: Stories of a First Nation, Métis, and Inuit cross-curricular infusion in teacher education. Learning Landscapes, 8(1), 305 - 321.

Yero, J. L. (2002). Teaching in mind: How teacher thinking shapes education. Hamilton, MT: MindFlight.

\section{Endnotes}

${ }^{1}$ In this paper, I use the term Aboriginal, which is inclusive of the Inuit, First Nations (formerly Indian), and Métis peoples of Canada, in a general sense. At other times, I use the term that is most appropriate for the particular context that I am addressing (i.e. First Nations or Indian).

${ }^{2}$ Interview protocol for the semi-structured interviews with the preservice teachers focused on three main areas: background experiences they had coming into the education program; what they learned from the partnerships about Aboriginal students, their families and communities; and how their learning about children's language and literacy learning was enhanced through their involvement in a situated and participatory experience.

${ }^{3}$ All names have been changed to protect anonymity.

${ }^{4}$ Content of this course includes an overview of the historical background of First Nations education in Canada and British Columbia, an examination of First Nations content in current curricula and the role of non-First Nations teachers in curriculum development projects, and an introduction to effective teaching practices for First Nations children, including building relationships with parents and community. 
${ }^{5}$ Taylor and Cranton's (2012), The Handbook of Transformative Learning: Theory, Research, and Practice, provides additional insight to this topic. 